\title{
97 rethinking the interplay of feminism and secularism in a neo-secular age
}

\author{
Niamh Reilly
}

\section{abstract}

The need to re-examine established ways of thinking about secularism and its relationship to feminism has arisen in the context of the confluence of a number of developments including: the increasing dominance of the 'clash of civilizations' thesis; the expansion of postmodern critiques of Enlightenment rationality to encompass questions of religion; and sustained critiques of the 'secularization thesis'. Conflicts between the claims of women's equality and the claims of religion are welldocumented vis-à-vis all major religions and across all regions. The ongoing moral panic about the presence of Islam in Europe, marked by a preoccupation with policing Muslim women's dress, reminds us of the centrality of women and gender power relations in the interrelation of religion, culture and the state. Added to postmodern and other critiques of the secular-religious binary, most sociological research now contradicts the equation of modernization with secularization. This article focuses on the challenges that these developments pose to politically oriented feminist thinking and practice. It argues that non-oppressive feminist responses require a new critical engagement with secularism as a normative principle in democratic, multicultural societies. To inform this process, the author maps and links discussions across different fields of feminist scholarship, in the sociology of religion and in political theory. She organizes the main philosophical traditions and fault lines that form the intellectual terrain at the intersection of feminism, religion and politics in two broad groups: feminist critiques of the Enlightenment critique of religion; and feminist scholarship at the critical edges of the Enlightenment tradition. The author argues that notwithstanding the fragmented nature of feminist debates in this area, common ground is emerging across different politically oriented approaches: all emphasize 'democracy' and the values that underpin it as the larger discursive frame in which the principle of secularism can be redefined with emancipatory intent in a neosecular age.

\section{keywords}

religion; feminism; secularism; multiculturalism; equality; rights 


\section{introduction}

Conflicts between the claims of women's equality and the claims of religion are well-documented vis-à-vis all major religions and across all regions (Sharma, 1987; Plaskow and Christ, 1989; Castelli, 2001; King and Beattie, 2005). Most recently, in Europe, enlargement and immigration have led to increased awareness of religious diversity and a moral panic about the presence of Islam in Europe. This is marked by the conflation of Islam with the threat of terrorism and a preoccupation with policing Muslim women's dress. In particular the 'Muslim headscarf' ' has become a powerful motif in pan-European debates on multiculturalism, symbolizing the challenges posed by new patterns of religious diversity to ostensibly European values. Chief among these values, it is asserted, are a secular public sphere and women's equality with men. In this discursive milieu, two interrelated sites of contestation feature prominently: a European secular public space and the veiled Muslim woman, whose presence is construed as threatening the supposed secularity of the public sphere, the norm of gender equality and, potentially, the security of the nation. There is no doubt that if a woman is coerced to dress in a particular way, to conform to a putative religious code, her human rights are violated. However, prohibiting Muslim women from wearing different forms of head covering in public settings to enforce a 'secular' vision of European modernity, or security, objectifies Muslim women as victims without agency, or as instruments of terror, with equally profound human rights implications (An-Na'im, 2007). As Sara Silvestri notes:

Forbidding by law a 'symbol' of perceived oppression does not equate with solving the oppression problem [where one exists]. It might even produce another form of oppression, of coercion of conscience on the part of the state which would go well beyond reasonable concerns and security priorities. (Silvestri, 2010)

While these events are unfolding in multilayered and nuanced ways, 'western feminism' has been implicated in the promulgation of punitive policies directed against Muslim women in the name of protecting women's rights and equality (Scott, 2007; Razak, 2008). From a perspective of commitment to feminism as emancipatory politics and to critical transformative understandings of human rights, the above scenario is of deep concern (Reilly, 2009). It raises major questions for feminist scholarship and practice extending beyond the 'Muslim headscarf' debate per se, which this article aims to address. The first set of questions relate to the prospects for articulating and enacting non-oppressive feminism(s). More than twenty years after the publication of Chandra Mohanty's influential critique of western feminist scholarship about 'third world women' (1988), in contemporary Europe, it must be asked: do women from the global South, and Muslim women in particular, continue to be constructed 'under western eyes' as passive, oppressed and in need of saving? Is a non-oppressive feminist philosophy and politics that both retains a commitment to women's
1 While recognizing that there is much diversity in the form and significance of different modes of Muslim women's head and body covering, I use the term 'Muslim headscarf' primarily in relation to the European context to connote all forms of head covering or dress used by women that signify Muslim female identity. 
human rights - economic, social and cultural in addition to civil and political and actively respects women's differences possible? If so, what are its principles and modalities?

The second set of questions concern the need to rethink how we understand the interplay of gender, religion and power, especially vis-à-vis the public sphere and the state. Feminist theorists have addressed the oppressive dimensions of religion in a number of ways. Some have developed critiques from within, offering alternatives to patriarchal interpretations of specific religious texts and practices (see Christ and Plaskow, 1979; Gross, 1992; Beattie, 2004). Most feminist political theorists, in contrast, have adopted an implicit alignment with 'secularism' and have paid minimal attention to religion as a category except to refer to 'religious freedom' as an established norm (Cornell, 1998) or to flag it as a source of harmful cultural practices (Okin, 1992, 1999) or an aspect of 'difference' (Young, 2002). This pattern in feminist theory literature is noticeably interrupted when the explicit focus is on 'women of colour' or women in global South contexts when religion often figures prominently whether as: a potential source of African American women's empowerment (see Hill Collins, 1990); or a nuanced site of contestation between the state and the Muslim minority in India (for example Pathak and Sunder Rajan, 1992). Most Anglo-American feminist political theorizing, however, appears to take for granted, implicitly or explicitly, that the public and societal relevance of religion is (or will be) inevitably diminished as a consequence of 'modernization'. Within this logic, religion need not be centrally addressed in feminist theorizing, except in relation to women marked by 'religiousness as difference' or vis-à-vis contexts that have yet to 'modernize'.

Increasingly, however, both the 'religious' versus 'secular' binary and the underlying assumptions of 'secular feminism' are being challenged in two key ways. First, feminist critics of the 'Enlightenment critique of religion' ( $E C R$ ) who draw especially on postmodern insights are questioning the coherence of the secularreligious binary within and beyond religious studies. The second challenge, coming mostly from sociological studies, calls into question, empirically and philosophically, the secularization thesis per se; that is, the narrative of a single modernity wherein religion is expected to become a much diminished and private aspect of people's lives. Most sociologists of religion now agree that, viewed from a global perspective at least, the presumption of secularization as an inevitable or uniform process is no longer tenable. There is less agreement, however, on the nature, scale and normative implications of the persistence of religion as a social, cultural and political force globally.

These developments have given rise to renewed debate across a range of disciplines about the role of religion in public life. Despite the profoundly gendered nature of religious beliefs, practices, organizations and actors, and their impact in shaping women's identities and lives, to date, there has been little debate on these matters between 'religious' and 'secular' feminist academics. In the field of the sociology 
of religion, critical analyses are emerging, which problematize the male bias in mainstream sociological interpretations of secularization to date (Woodhead, 2008). More broadly, it is increasingly recognized that religion and experiences of secularization (or not) are encountered differently along gender lines as these intersect with other aspects of identity and experience, especially class, 'race', ethnicity and geo-cultural location (Vincett et al., 2008). It follows that such differences must be taken into account to better understand and interpret changing gendered patterns in religious (and spiritual) practices and the implications for the ongoing theorization of secularization. This article contributes to the complex gendering of secularization theory, with a particular focus on how we think about and enact 'gender equality' and 'women's human rights' in contexts of a new, renewed or persistent presence of religion in the public sphere. An overarching purpose, therefore, is to map and link discussions across different fields of feminist scholarship, in the sociology of religion and in relevant currents in political theory. In doing so, I intend to posit a non-oppressive feminist response to current challenges around the interplay of religion, culture, secularism and the prospects for women's equality and human rights - formal and substantive - in democratic polities.

\section{rethinking secularization}

This section outlines some key trends in academic debates on secularization and begins to consider their implications for rethinking secularism as a normative feminist principle. David Herbert summarizes the main tenets of the 'orthodox' secularization thesis that has underpinned most sociological accounts of religion until relatively recently. Secularization theory posits secularization as an inevitable consequence of modernization characterized by: (1) social differentiation; (2) societalization; (3) rationalization and (4) 'worldliness' (Herbert, 2003). First, secularization has been understood as an effect of the differentiation of society into semi-autonomous spheres (e.g. political, legal, economic, scientific, educational etc.) which fulfil various social functions according to the 'scientific' knowledge governing each domain. In the process, the relevance and influence of religion and religious institutions is increasingly squeezed out and limited to the domain of people's personal lives. Second, societalization refers to the decreasing incidence of face-to-face community and the rise of anonymous sub/urbanization, which erodes the hold religious values and leaders traditionally have had over individuals. Third, rationalization describes a host of ways of explaining and representing how humans are, which it is argued ultimately trumps religious belief and superstition as ways of making sense of and shaping our world. Finally 'worldliness' describes a tendency some scholars argue is increasingly evident wherein religions are becoming more oriented towards social or 
political issues, or self-improvement, and less concerned with 'transcendence' of the material world; that is, a kind of 'internal secularization' of religions.

\section{empirical evidence on secularization}

The empirical evidence on actual patterns of secularization in different contexts is contradictory. Focusing on declining rates of church attendance and/or membership in the most stable, and prosperous nation states in North west Europe, for example, Steve Bruce (1996) argues that there is a decisive overall trend toward secularization as 'modernization' occurs. However, against this, he also finds that participation in traditional religious practices remains high in countries where the formation of national identity and religion have been intertwined historically (for example Ireland, Poland). Pippa Norris and Ronald Inglehart (2004) also lend continuing support to the secularization thesis. Drawing on World Values Survey data (1981-2001), they argue that secularization understood as a 'systematic erosion of religious practices, values and beliefs has occurred most clearly among prosperous social sections living in affluent and secure post industrial nations' (Norris and Inglehart, 2004: 5). In contrast, others have argued that societies in different parts of the world (especially beyond Europe) are actively 'de-secularizing' in various ways, evidenced by the rise of new religious and spiritual movements and practices (Berger, 1999; Davie, 2002; Herbert, 2003). Heelas et al. (2005) offer support to both sides of this debate; focusing primarily on evidence from the United Kingdom (UK), they concur that secularization, understood as the declining influence of organized religions and churches, has accelerated since the 1970s, while at the same time different forms of 'spiritualism' have gained followers in both the UK and the United States. Underlining the interrelation of descriptive and prescriptive accounts of secularization, and echoing arguments by feminist writers discussed further below (Shaheed, 1989; Al-Ali, 2000), Herbert also notes that in post-colonial contexts where the 'secular state' is construed as an imposition from the west, critiques of indigenous religions are unlikely to garner popular support or legitimacy (Herbert, 2003: 55).

Particularly relevant to this article, focusing on religion in the public sphere, José Casanova's comparative study of Brazil, Poland, Spain and the United States (1994) leads him to conclude that outside of Europe the 'de-privatization' of religion is underway. In particular, he cites examples of religious actors shaping public debate in the United States as one influence among others in civil society. He suggests that aggressively enforcing the separation of church and state (for example in France) is unique to the European ECR, which was driven by a rejection of particular, context-specific links between churches and authoritarian regimes in Europe. Recently, updating his theory of public religion (and building on work by Alfred Stepan), Casanova argues that religion de facto has been

continually present in public spheres in a majority of contexts, including 
long-established democracies, despite the rhetoric of the 'secular modern state' (Stepan, 2000; Casanova, 2008). These conclusions are also consistent with recent findings of the $\varepsilon U$ VEIL research project (Values, Equality in Liberal Democracies), which adds a feminist dimension to empirical work that contradicts a singular secularization thesis. This seven-country European study documents much variation within Europe in state responses to the 'Muslim headscarf', which is linked to significant differences in the model of church-state relations, traditions regarding antidiscrimination, and prevailing cultural and legal concepts of citizenship in each of the countries studied (see Kiliç et al., 2008).

\section{the concept of neo-secularization}

Recognizing that there is considerable variation in actual patterns of secularization in different contexts, and that teleological assumptions of a singular, inexorable path of secularization are untenable, is secularization still a valid concept? Eschewing postmodern declarations of the dawn of a post-secular modernity wherein the 'secularization as modernization' thesis is completely jettisoned, most scholars in the field of sociology of religion have not abandoned the concept. Instead, they have, to one degree or another, sought to develop more nuanced and complex frameworks for researching and analysing secularization, which some label neo-secularization (Chaves, 1994). Reflecting this broad approach, Herbert stresses the need to distinguish between the political and social 'significance' of religion and its cultural 'vitality'. While it is generally agreed that the former has declined, at least in Europe, he argues that the failure to pay attention to continuing and/or changing forms of cultural significance of religion in all societies is a major gap in analyses that only consider the formal influence of religion. Scholars in this vein, therefore, call for multilevel analyses (micro/individual, meso/organizational, macro/societal) that map the relationship between social change and religious change in contextspecific studies (Malesevic, 2010). Building on Chaves, in an analysis of secularization in Ireland, Malesevic posits a framework of neo-secularization that does not privilege questions of decline or renewal of religion, but rather focuses on understanding the 'changing scope of control exercised by religious authority in various spheres of life' in any given context. This approach with its attention to 'the scope of religious authority' and openness to diverse patterns of secularization is, I believe, particularly pertinent to the task of rethinking the interplay of feminism and secularity in the public sphere in multicultural, democratic polities; a point I return to in the conclusion of this article.

\section{secularization debates and normative political theory}

Most of the debates reviewed in this section have arisen in the context of an empirically focused sociology of religion. Unsettling the 'secularization as modernization' thesis, however, profoundly affects core ideas in the understanding 
and practice of politics in contemporary democracies in the global South as well as the North, not least the separation of 'church and state' and the 'rule of (secular) law'. While debate on the nature of secularization and the role of religion in the public sphere is advanced in sociological analysis, political theorists, especially in Kantian liberal (for example John Rawls) or social democratic traditions (for example Jürgen Habermas) have been much slower to engage with these debates. In the liberal-communitarian divide that has structured much debate in political theory since the 1990s the communitarian side is more disposed to addressing religion and morality as constitutive features of political life. Communitarian thinker Michael Sandel (2006: 146) notes: 'Liberals often worry about religion in politics because they associate religion with intolerance [and the] resolve to avoid wars of religion has shaped much liberal political thought'. Despite the appropriation of communal values by conservatives in the United States and elsewhere, he argues that 'there is nothing intrinsically conservative about family or neighbourhood or community or religion' (Sandel, 2006: 42). Rather, he cautions that a 'vision of public reason [that] is too sparse to contain the moral energies of a vital democratic life ... opens the way [in public life] for the intolerant and the trivial and other misguided moralisms' (Sandel, 2006: 246).

As the critique of the secularization thesis deepens, however, debate is emerging even in those currents of normative political theory criticized by Sandel, which have been most resistant to a role for religion in the public sphere. Most notably, Habermas in recent writings concedes greater space to religious-based arguments within his account of dialogic rationality, which for him underpins democratic societies. He argues:

\footnotetext{
The liberal state has an interest in the free expression of religious voices in the public arena... It must not discourage religious persons and communities from also expressing themselves as such in the political arena, for it cannot be sure that secular society would not otherwise cut off itself from key resources for the creation of meaning and identity... Religious traditions have a special power to articulate moral intuitions, especially with regard to vulnerable forms of communal life. In corresponding political debate, this potential makes religious speech a serious vehicle for possible truth contents ... . However the institutional thresholds between the 'wild' political public sphere and the formal proceedings within political bodies also function as a filter that allows only secular contributions from ... the informal flows of public communication to pass through. (Habermas, 2008: 131)
}

Concurring with the position expressed in Casanova's earlier work (1994), therefore, Habermas limits the role of religion to opinion formation in the 'weak' public sphere of civil society (as distinct from policy and law making) (Cooke, 2007: 227). 
In summary, this article aims to consider more closely the gender dimensions of the foregoing debates in the sociology of religion and normative political theory. Specifically, it is most concerned with examining their implications for how to conceptualize and act on commitments to women's human rights in nonoppressive ways in multicultural and democratic polities. As demonstrated by recurring contentious 'Muslim headscarf' debates in Europe, rethinking secularism and the limits of secularity in democratic societies has major implications for how ideas of gender equality, and indeed feminism as a political project, are defined and enacted. This article proceeds from the premise that feminist approaches that contribute to the construction of non- $\varepsilon U$ immigrant women (especially Muslims) as the antithesis of western democracy and secular modernity are untenable as a basis for emancipatory politics. Equally, it problematizes situations in the global South, where indigenous women's organizations that support women's access to reproductive healthcare (Amin and Hossain, 1994) or directly challenge politicized autocratic religious forces (Al-Ali, 2000; Othman, 2006) are discredited and suppressed by association with the 'secular', the 'west' and 'feminism'. Ultimately, I argue that articulating emancipatory feminist politics that is capable of addressing both contexts without reproducing western-centric hegemonies demands critical scrutiny of 'secularism' as a feminist principle in ways that respond to both liberal concerns about intolerance and communitarian critiques of the oppressive exclusion of religion from the public sphere. Towards this end, the next two sections set out the major philosophical traditions and fault lines that form the intellectual terrain at the intersection of feminism, religion and politics. Unsurprisingly given the complexity and contested nature of this terrain, feminist debates on these matters are also polarized and fragmented. For the present purposes, I cluster the different approaches in two loose groups: first, feminist critiques of the $E C R$; and second, feminist scholarship at the critical edges of the Enlightenment tradition - conscious of the shortcomings of the legacy, but retaining a commitment to the radical promise of its ideals. The latter in particular encompasses what is generally understood as 'secular feminism'. These two sets of thinking are discussed in the next two sections, respectively.

\section{feminist critiques of the $\varepsilon C R$}

In Reclaiming the Enlightenment (2004: 2), Stephen Bronner contextualizes the Enlightenment historically as an intellectual project concerned with articulating the conditions of human liberation. Its spirit, he argues, and the 'foundation for any kind of progressive politics' is its emphasis on 'autonomy, tolerance and reason'. These basic Enlightenment tenets he insists still 'run directly counter to the exercise of arbitrary power [in all its forms] no less than the censorship, collectivism, and conformism of authoritarian or totalitarian regimes of both the 
left and right' (Bronner, 2004: 8). Conservatives, therefore, have always stood against the Enlightenment for its 'devastating assault on communal life, religious faith, social privilege and traditional authority' (Bronner, 2004: 1). From the midtwentieth century however, the Enlightenment began to be the target of critique from the intellectual left. Most notably the influential Dialectic of Enlightenment (Horkheimer and Adorno, 1972) equated Enlightenment reason with the instrumental rationality of domination. These ideas resonated particularly in subsequent feminist critiques of Enlightenment epistemology as constituted by false gendered hierarchical binaries and abstract individualism. The critique of the Enlightenment has gathered momentum more generally among postmodern thinkers, especially over the past two decades. The crux of the problem, Bronner argues, is that while the Enlightenment intended to foster human liberation through among other things a rejection of religious dogma, 'scientific reason ultimately wound up being directed not merely against the gods, but all metaphysical ideas, including conscience and freedom' (Bronner, 2004: 3). In this section I discuss three currents of feminist scholarship that have challenged the $\varepsilon C R$ in different ways. These are: feminist studies in religion (FSR); postmodern feminism; and feminist communitarian political theory.

\section{feminist studies in religion}

FSR has roots in 'second wave' feminism of the late 1960s and 1970s which sparked new critical engagement with religion, shaping a substantial and still expanding literature on women and gender in religion. Initially, the main orientation of this work was to challenge the 'problematic nature of exclusively male God-language' and the 'falsity of dualistic thinking' - principally in Judeo-Christian traditions while 'valuing women's experiences and history' in religion and arguing the 'need to create new ritual as well as theology' (Christ and Plaskow, 1992: vii). Still influential today, such efforts to develop postpatriarchal (re)interpretations of religious texts, traditions, practices, representations and histories were especially formative through the mid-1990s (Daly, 1978; Christ and Plaskow, 1979; Schüssler Fiorenza, 1984/1994; Gross, 1996). Since its inception, not least in response to early trenchant criticism about the failure of the new discipline to include the perspectives and analysis of women of colour (Lorde, 1984), FSR has evolved into an inclusive and multidisciplinary intellectual space. In recent decades, FSR has responded to various challenges to 'nuance and deepen ... [feminist] understandings of religion' (Plaskow, 2001: 536). This is evident in a steady growth of writing emphasizing the diversity of women's experiences and identities within and across religious traditions, especially in terms of 'race', ethnicity, class, sexuality and location (Plaskow and Christ, 1989; King, 1995; King and Beattie, 2005). It is also reflected in the influence of postmodern intellectual currents and a general shift away from 'essentialist' understandings of women and gender in religion (Daly, 1978; Starhawk, 1979) in favour of constructivist approaches (King, 1995; Anderson and Clack, 2003). FSR, therefore, has yielded a rich body of scholarship 
both within the discourses of theology as well as in philosophy, psychology and psychoanalytic theory and anthropology, classics, history and literature, which has been largely bypassed in 'secular' feminist literatures.

By definition, FSR, as part of theology and/or religious studies, represents a persistent though marginalized challenge to the $\varepsilon C R$. In contrast, since the 1990s, the postmodern intellectual movement has been extremely influential in challenging Enlightenment thinking more broadly and unsettling epistemological underpinnings in many disciplines across the humanities and social sciences. On the face of it, anti-universalist, postmodern philosophy directed at the deconstruction of grand narratives is an unlikely ally of theology. Recently, however, scholars in FSR are increasingly drawing on now widely established feminist/ postmodern insights to contest the secular-religious distinction as a false and oppressive binary. For example, Tina Beattie argues that defining religionfocused scholarship as either: religious/biased or secular/impartial, fails to understand core feminist epistemological insights including 'recognition that the researcher and researched are caught up in a mutually subjective and transformative encounter that involves a high degree of personal commitment and trust'. Instead, Beattie notes, the secular-religious binary reinforces a false idea of religion as a 'reified and bounded "thing"... in a scientifically and rationally knowable universe' (Beattie, 2005: 68).

Elizabeth Castelli also problematizes the operation of the secular-religious divide along similar lines:

\footnotetext{
It has been an obstacle to some conversations that many feminists, whether activists or academics, have tended to read 'religion' as an abstraction solely in negative terms reading 'religion' only as a constraint ideologically and institutionally, and reading the embrace of religious affiliations or allegiances as a sign of false consciousness. This negative rendering of 'religion' is in many respects an ironic holdover from Feminism's own Enlightenment inheritance. (Castelli, 2001: 5)
}

Arguably however, this stand-off is beginning to shift as elements of a common analytical approach come into focus. Sustained critiques of Enlightenment rationality and progress (exemplified in the secularization thesis), combined with the normative imperative felt by many to formulate non-oppressive responses to the ongoing moral panic around 'Islam in the west', appear to be opening new avenues of potential dialogue across the hitherto polarized areas of 'secular' feminist scholarship and FSR. Perhaps ironically, this is most evident in the increasing engagement of influential 'secular' postmodern feminist thinkers with questions of religion, secularism and the public sphere.

\section{postmodern feminist interrogations of secularism}

Recent work by Joan Wallach Scott and Judith Butler exemplify a new, explicit postmodern feminist engagement with religion, which extends feminist critiques 
of the $\varepsilon C R$. Specifically, their analyses explicate the oppressive discursive practices that attend the gendered operationalization of 'secularity as modernity' culminating in, as Judith Butler describes it, 'cultural assaults' on religious minorities (Butler, 2008: 3). In the Politics of the Veil (2007: 95), addressing recent events in France, Scott argues that our ideas about secularism 'structure the way we think about how to deal with religion in general and Islam in particular'. She problematizes normative secularization theory which conflates 'secularism' with forward-looking 'modernity' and 'democracy', and the ECR, which demands the triumph of reason over superstition, sentiment and belief. The impetus to the stark separation of church and state, she argues, originates in this logic which casts 'religion' as a backward looking remnant of the past, while the state becomes 'modern' through the suppression of religion. The 'Muslim headscarf' controversy as it has played out in France typifies this oppressive discursive process wherein state actors, ostensibly in the name of preserving secularity, seek to erase religious signifiers from the public realm - in this case Muslim women's dress.

Offering an alternative vision, Scott challenges the idea of religion as the antithesis of secularism. She suggests that democratic states and religions (or at least 'some religious denominations') might be viewed as 'parallel systems' of interpretation. The State promulgates constitutions and laws interpreted by judges and lawyers, she posits, while religions defer to sacred texts interpreted by theologians and religious leaders (Scott, 2007: 96). Rejecting the antithesis between religion and secularism, Scott argues, 'opens the relationship between the state and its religions to negotiation without either forcibly repressing religion or giving up democracy - which remains a place where political resolution is never achieved on the grounds of religious truth' (Scott, 2007: 96). Very significantly, in keeping with Habermas' inclusion of 'religious speech' in public sphere deliberations, Scott flags the caveat that this idea of parallel systems should not be taken 'too far' and that in democratic secular states 'the relationship between the political and the religious is asymmetrical' whereby 'democratic states have coercive power that exceeds any influence religion may have' (Scott, 2007: 96). Overall then, Scott appears to affirm a form of dialogic democratic pluralism, wherein the constitutional 'rule of law' ultimately trumps 'religious law' to protect against religious absolutism. Similar to Casanova's public religion, Scott posits a constructivist account of French secularism not as a universal law but as the particular outcome of historical experience in the Christian nations of western Europe:

The principle of secularism might be described historically as one which protects the political sphere from the determining influence of a dominant religion while recognizing religion's public (social, cultural) importance - it is not only a private, individual matter. (Scott, 2007: 97)

Hence, 'drawing the line on Islam' through attacks on the Muslim women's dress, Scott argues, is a 'distortion of that nation's own history'; such actions she 
argues have more to do with excluding Muslim populations from France than defending the European values of secularity or indeed gender equality.

Judith Butler similarly contests dominant 'secular conceptions of history' that rely on:

a certain version and deployment of 'freedom' [that] can be used as an instrument of bigotry and coercion. This happens most frightfully when women's sexual freedom or the freedom of expression and association for lesbian and gay people is invoked instrumentally to wage cultural assaults on Islam that reaffirm US sovereign violence. (Butler, 2008: 3)

Citing a European example of a Dutch immigration citizenship test, which requires a tolerant response to images of two gay men kissing (by Muslim applicants in particular), she asks if 'the struggle against homophobia must contradict the struggle against cultural and religious racisms ... [where] there are no points of cultural contact between sexual progressives and religious minorities that are not encounters of violence and exclusion'? This antinomy, Butler argues, flows from 'a restrictive idea of personal liberty that is bound up with a restrictive conception of progress' (Butler, 2008: 6). Instead she calls for a 'focus on the critique of state violence and the elaboration of its coercive mechanisms' in order to generate 'an alternative political framework' and 'another sense of modernity' (Butler, 2008: 6). Importantly, like Scott, Butler also couches her critique within a commitment to democratic politics; she underlines that her point is 'not to abandon freedom as a norm' but to 'resist its coercive instrumentalization ... and [to] have another meaning that might remain useful for a radical democratic politics' (Butler, 2008: 3).

From Scott's perspective, with which I agree, the preoccupation with enforcing the principle of secularism is the wrong one; the real concern is 'the democratic outcome' (2007: 94), which for Scott necessarily entails accommodating a public role for religion. This return to the state as a privileged site of power is a significant departure in postmodern analyses. For Scott and Butler the imperative of focusing on the state arises from their critiques of state violence against Muslim communities and individuals. Scott correctly highlights how some western feminists have been complicit in the instrumentalization of 'equality' in a wider politics of western neo-imperialism (Scott, 2007: 168-169). Similarly, Butler sees 'a restrictive idea of personal liberty' (i.e. liberal, individualist, rights-based ideas of liberty) as implicated in oppressive immigration policy practices (Butler, 2008: 6). In this regard, Scott and Butler leave little room to salvage equality and human rights-based contestations of gender based oppression, especially as it intersects with other forms of oppression, based on 'race', religion, and so on. More positively, and perhaps intimating a move to reclaim the emancipatory values of the Enlightenment, they pin their hopes for addressing such abuses in some form of democratic renewal, which they point to but do not fully develop. It is difficult to envisage how these hopes can be realized, however, unmoored from 
critically reinterpreted, bottom-up principles of equality and human rights. I will develop this point further in subsequent sections.

\section{communitarian feminism and religion in the public sphere}

The third strand of feminist scholarship that expressly challenges the ECR has roots in communitarian political philosophy. Defined chiefly by a radical critique of liberalism, and the assumption of atomistic individualism on which it relies, the communitarian tradition is the stream of political theory most associated with the positive accommodation of religion in modern democratic societies. Communitarian thinkers espouse a positive ontology of belonging to community, with many arguing for the importance of recognizing and respecting group identities, values and practices. This tradition is associated both with conservative values-driven visions of the 'good society' and with progressive multicultural politics (see Young, 2002). The contributions of Scott and Butler may be read as adding a sharp gender focus to the wider literature on multicultural politics, wherein the chief concern has been to problematize evolving forms of intolerance against minority ethnic communities in Europe, including religious intolerance (Modood et al., 2006; Levey and Modood, 2009). In addition, within the narrower purview of communitarian political theorizing, philosophers including Jean Bethke Elshtain (2009), Michael Sandel (2006) and Charles Taylor (2009) have been particularly disposed to critically examining the operation of secularism in democratic societies. In this sense, the communitarian tradition has clear resonances with FSR, which views religion as a potentially positive space for women (while also challenging its patriarchal and sexist manifestations).

Communitarian Jean Bethke Elshtain arrives at similar conclusions to Joan Scott on the principle of accommodating religion in the public sphere within democratic politics. Echoing Scott's analysis, she is highly critical of the French model of secularism (Laïcité) as a 'state enforced civic religion' (Elshtain, 2009: 9) that imposes a false choice between Laïcité and 'Islamic fundamentalism'. (Lending support to this view, Scott's account of how French society has historically accommodated Catholic practices, for example, by allowing children time off school for religious instruction or not banning the wearing of crosses, underlines the double standard in enforcing secularism; the flexibility shown to Christian practices, which ethnocentrically are constructed as compatible with 'secularism', stand in stark contrast to the intolerance shown to Muslim practices.) Insisting on a rigid vision of the 'secularized' civil society, Elshtain argues, effectively militates against the integration of Muslim communities in western societies. She also draws attention to the historically positive relationship between religion and politics in the United States. She endorses American democracy wherein she suggests 'a dialogic system emerged that combined a secular state with a democratic civil society' in which religion has always played a catalysing role evident in anti-slavery, workers', women's suffrage, and civil 
rights movements (Elshtain, 2009: 10). Unusually, communitarian and postmodern critiques overlap as Elshtain and Scott both locate the solution to new challenges posed by the apparent rise of religion in the west in dialogic democratic practice.

In conclusion, primarily through concerns about the definition and operation of secularism, the foregoing discussion highlights the emergence of a common analysis across currents of feminist scholarship that have hitherto occupied disparate locations along the philosophical and ideological spectrum. Scholars in FSR and feminist postmodern thinkers increasingly share a critique of the inimical discursive effects of a rigid religious-secular dichotomy. Implicated in new forms of state violence against religious minorities, this discursive binary has also operated to close off potentially transformative dialogue across supposedly irreconcilable domains of 'religious' and 'secular' feminisms. As noted by Bronner, communitarian critiques of 'aggressive secularism' are predictable. However, from a political theory point of view, it is significant that in seeking to address challenges around the presence of 'Islam in the west', communitarian and postmodern feminist critics appear to be formulating similar assessments of what remedial action would be. This includes more flexibility in accommodating religion in the public spheres of multicultural democratic societies and in operationalizing a critically revised principle of secularism in democratic secular states. Like other influential thinkers in the communitarian tradition, Elshtain makes this argument from a point of view of commitment to the role of tradition, values and religion as integral to public life and the vitality of communities in a democratic society. In contrast, the conclusions of both Scott and Butler, while eschewing traditional Enlightenment negative characterizations of religion as a privileged site of oppression, are nonetheless more concerned, politically speaking, with responding to the tyranny of intolerance than with recognizing religion as a potentially positive site of freedom, although this assumption is implicit. Arguably, the postmodern return to the political, reflected in these debates, suggests the beginning of a re-evaluation of the omnipresent critique of the Enlightenment that has been the hallmark of the postmodern intellectual movement and the rehabilitation of its ideals of autonomy, tolerance and reason (freed from dominating rationality). If this is the case, such a turn could (re)discover common ground, not only with progressive communitarian currents, but also with feminist approaches to religion on the critical edges of the Enlightenment tradition discussed in the following section.

\section{feminism, religion and democracy on the critical edges of the enlightenment}

In feminist scholarship that is critical of the Enlightenment but retains a significant commitment to the radical promise of its ideals, there are two 
dominant approaches to religion: first, as noted earlier, feminist political and social theorizing that typically deals with religion as an absence; and second, a substantial body of feminist political sociology, which primarily focuses on the harmful effects of politicized religion and religious fundamentalisms (Jeffery and Basu, 1998; Anwar, 2009; Shaheed, 2009).

\section{the absence of religion in feminist theory}

Especially in the work of influential western feminist political theorists, religion is generally ignored as an empirical horizon or as a category of analysis. While not a conclusive test, a cursory review of the index pages of a selection of widely used texts in the field (Okin, 1992; Hartsock, 1998; Young, 2002; Bryson, 2003; McLaughlin, 2003; Harding, 2004) indicates that none have included 'religion' or a related term. Notably, however, feminist theory texts that focus on the experiences and perspectives of women in the global South tend to include substantially more references to religion, although usually along the negative lines noted above, also evident in the political sociological literatures (see Nussbaum, 2000; Mohanty, 2003; Tripp et al., 2009; McCann and Kim, 2010).

On one level the absence of religion even in western feminist political theory is puzzling. As an area of scholarship concerned with examining the gendered exercise of power across public and private domains, clearly much remains to be interrogated within all major religions wherein: 'men hold most or all of the roles of authority and prestige' and 'from these positions ... control and dictate the norms of the [religion] for all women' (Gross, 1996: 106). On another level, the silence on religion confirms the observations of Beattie and Castelli that most such scholarship retains an unexamined Enlightenment view of religion - as the antithesis of rationality and freedom. Aside from burgeoning critiques of the secularization thesis per se, however, the persistence of this view of religion in feminist political theory is at odds with quite basic feminist critiques of the public-private divide, which now underpin the most moderate liberal feminist agendas (evidenced, for example, by the focus on remedying domestic violence or securing 'family friendly' conditions of work). Hence, even if it is accepted that the influence of religion is or ought to be confined to the 'private sphere', it surely remains relevant to the theorization of the gendered exercise of power along the personal to political spectrum? This point is especially salient in light of research indicating that women make up the majority of actively religious people worldwide (Furseth and Repstad, 2006: 190-191; Woodhead, 2008). Hence, if women make up the majority of religious (or spiritually oriented) people, it follows that 'feminism' - as a conceptual and practical project concerned with the 'emancipation of women' - must acknowledge the role of religion in women's lives in more complex and nuanced ways than has happened to date. 


\section{western centric treatments of religion}

As flagged earlier, the presumption of religion as non-relevant in influential feminist theory texts highlights a problematic western bias. It assumes that regressive, gendered religious practices are really only a problem for women in societies that are 'not modern' (i.e. in or from the global South) who, within this logic, are generally construed as 'victims' of 'religiousness as difference' or 'religion as culture'. Religion is rarely seen as a problem in the same way for western 'religious women' who are more likely to be understood as complex subjects negotiating contradictory identities and demands (for example Catholic women who use contraception or conservative women who champion 'equal but different' arguments about gender roles). Moreover, at a macro level, the secularization thesis as a hegemonic European narrative has meant that countries like Ireland or Poland (where Catholic actors/values continue to exert considerable influence in state law, policy and services) are seen as 'exceptions' in an otherwise 'modern' European context. Approached instead through a neosecular lens, such examples come into focus as evidence of the need for ongoing scrutiny of the 'scope of religious authority' in the public sphere and its role in promoting or impeding gender equality for different groups of women and men in democratic polities.

Undoubtedly, much feminist scholarship at the intersection of religion and politics has roots in a liberal Enlightenment tradition epitomized by a commitment to women's equality and human rights. However, despite 'freedom of religion' also being a cornerstone of this tradition, because religion is frequently implicated in endorsing subordinate roles for women relative to men and/or harmful cultural practices, equality and rights feminism tends to view religion primarily as a threat. Much criticism has been levelled against this brand of feminist thinking as inevitably western-centric and neoimperialist (Grewal, 1999; Razak, 2008). Susan Okin's essay 'Is Multiculturalism Bad for Women' (1999), for example, is often cited (somewhat unfairly) as epitomizing this unreconstructed, universalist position; wherein the experience and worldview of white, western, middle class and, ostensibly, secular women is falsely universalized as the norm of 'modern emancipated womanhood'. This variant of western feminism mobilized in the context of the 'Muslim headscarf' debates against unemancipated 'other' women and the men who oppress them, is rightly castigated by Scott and Butler.

\section{politicized religion: global south perspectives}

Blanket critiques of feminist analysis that retains a commitment to Enlightenment norms, however, often belie the counter hegemonic, post-colonial moment of much theorizing in this tradition. This includes a large nuanced literature by feminists writing from various global South standpoints about global South contexts including Egypt, Malaysia, India, Iran and Pakistan (see Jeffery and Basu, 1998; Al-Ali, 2000; Narayan, 2000; Bayes and Tohidi, 2001; Othman, 
2006; Anwar, 2009; Badran, 2009; Shaheed, 2009). While the arguments of these scholars are complex and varied, they share a common critical orientation that challenges gender inequalities in context, rejects cultural essentialism, and aspires to the substantive realization of gender inclusive visions of democracy and human rights. Unsurprisingly, this scholarship focuses especially on problematizing politicized autocratic religion ('religious fundamentalisms') and highly relativist multicultural politics, which actively oppose or occlude recognition of oppressive gender practices in the name of 'religion' or 'culture' - challenges that have been exacerbated over the last decade in the context of the 'war on terror', which takes different forms in different geo-political settings.

The 'war on terror' narrative is infused with gendered and racialized perceptions prevalent in the west, which equate Islam with fundamentalism and 'terrorism'. This makes Muslim and other minorities in the west more vulnerable to intolerance, discrimination and state-sponsored abuses of human rights (Fekete, 2004). In addition to affecting women as members of targeted minority communities, as seen in conflicts over the 'Muslim headscarf', these trends have wider gender-specific implications. For example, minority women often play a daily interfacing role between their communities and the majority population (for example, around accessing housing, education, healthcare and other services) and, in this regard, can bear the brunt of prejudice and discrimination against the community, which they are perceived to represent. Further, in situations of heightened tension between minority and majority communities, minority women who are experiencing abuse within the family or community are extremely unlikely to seek assistance if they fear that they will be stigmatized for betraying the community and/or that they or their abuser will be subject to maltreatment by the authorities.

In this context, feminist critics of religious fundamentalist movements (Imam and Yuval-Davis, 2004; Saghal, 2004) have problematized how some multicultural political positions in the west, ostensibly aiming to redress harms caused by imperialism and contemporary forms of racism and xenophobia, work against women. Flagging the dangers of communitarian politics, Saghal has criticized British multicultural policy in particular, which initially allowed certain social policies to be determined by conservative male community leaders. In response to 'secular' Asian feminist pressure to address crimes against women in these contexts (especially forced marriage), British politicians and policy-makers, reflecting a dominant progressive understanding of multiculturalism, looked for religious arguments (Hindu, Sikh, Muslim) to justify legal and policy interventions against forced marriage. In doing so, however, Saghal argues, they 'resorted to developing support amongst the very people [they] wanted to criticise, and thereby helped increase their hold over "their" communities' (Saghal, 2004: 58). Similarly, regarding 'Muslim headscarf' debates, arguments from a multicultural perspective can err in focusing only on impediments to Muslim women to wearing 
Muslim dress, but not on the right of a Muslim woman not to do so if that is her wish. In doing so, they fail to acknowledge and address the conflicts that regularly arise when the self-determination of a woman clashes with the 'beliefs of the community'. This underlines that, to the extent there is a problem in relation to a woman wearing a 'Muslim headscarf' or not, it is the problem of maximizing the conditions of her self-determination. If a woman is forced to, or prohibited from, wearing any form of 'Muslim headscarf', whether by an individual or a state actor, it is equally unacceptable from an emancipatory feminist perspective.

In global South contexts, cultural essentialist arguments are similarly mobilized by autocratic, politicized religious movements that conceal gender-based oppressions in the name of enforcing authentic communal religious integrity and rejecting western secularism. Such movements tend to emerge in situations of rapid social change. Around the world, processes of decolonization, national independence, modernization and globalization have generated a 'bewildering pace of change' and a need to construct new histories and (re)create identities and ways of belonging at the individual, community and national level (Shaheed, 1989: 4). In the global South, most fundamentalist initiatives have roots in a legacy of western 'colonisation and hegemonic rule and control' (Shaheed, 2004: 3). After the initial optimism prompted by decolonization processes in the 1950s and 1960s, disillusionment set in as it became clear that none of the available paradigms - nationalism, capitalism or communism - could meet most people's material, social and spiritual needs (Imam and Yuval-Davis, 2004).

Writing about secularism, gender and the state in Egypt, Nadje Al-Ali (2000) is highly critical of the now hegemonic scholarly literature from 'the Islamic perspective' that takes as given the 'unequivocal equation of secularism with the "west" and "Christianity"'. (The presumption of human rights as an inherently western concept reflects a similar logic.) Al-Ali problematizes this relatively new orthodoxy in Egypt and the Muslim world more generally, characterizing it as a perpetuation of ahistorical orientalist thinking and 'an essentialist presupposition that has to be challenged' (Al-Ali, 2000: 131). Such essentialist arguments promulgate a false dichotomy that permits only two possible standpoints in postcolonial contexts: either to defend 'authentic' local culture against 'the west' or to collude in the neo-imperialist imposition of western values and agendas. Within this logic, which is at the heart of contemporary Islamist autocratic projects, internal dissent is not simply absent but ineffable as critical voices are only heard as 'westernized' betrayers of Islam and local culture - with feminist voices especially castigated as 'western' (Shaheed, 1989; Mukhtar, 2003). This logic is deeply disingenuous. It denies the agency and 'belonging' of locally situated, indigenous dissenting subjects who both: (1) articulate women's equality or human rights claims in their own contexts; and (2) firmly reject the 
imposition and false universalization of human rights values from various dominant standpoints, internally or externally.

Norani Othman is a leading feminist and Islamic scholar from Malaysia who has analysed the deeply gendered nature and impacts of autocratic religious political movements in Southeast Asia. She argues that women are the main losers in the ongoing wave of Islamization in the region. While Shari'a law has been a feature of most Muslim societies historically, she notes that recent decades have seen the introduction of 'more and more Muslim laws that are retrogressive for women' (Othman, 2006). In Malaysia, the process began in the 1980s when the National Front coalition government led by Mahathir Mohamad endeavoured to win the support of the majority Muslim population and keep the more radical Islamist party (PAS) out of power. A process of systematic administrative and legal reform ensued, which put over 100 Islamic scholars at the centre of federal policy-making mechanisms. At the same time, the Shari'ah judicial and legal system was strengthened and extended to the detriment of women (0thman, 2006: 344). In particular, 'polygamy and divorce have been made easier for men' and, increasingly, women who have been 'divorced, abandoned, beaten up or neglected by their husbands ... complain of injustice and discrimination in their search for redress through Malaysian Shari'ah courts' (Othman, 2006: 344).

To conclude, this section has considered approaches to religion and politics in feminist scholarship that sit broadly within a critical Enlightenment tradition. While Castelli's criticism that this work treats religion primarily as a negative and a constraint are confirmed, it is important to bring into focus the political conditions that often shape such views. At the same time, in the examples discussed here from the United Kingdom, Egypt and Malaysia, essentialist understandings of the secular-religious binary are as vigorously contested as they are by Butler, Scott and others writing from 'anti-Enlightenment' perspectives (discussed in the previous section). For the latter, the western secular state is implicated in denying 'freedom of religion', justified by essentialized, orientalist understandings of the threat of 'Islam' as irrational and dangerous. For the scholars highlighted in this section, politically powerful authoritarian religious actors (who are also often state actors) are implicated in the coercion of religious conformity. Such processes are rendered legitimate as modes of opposition to essentialized understandings of the threat of 'the west' as individualistic, atheistic and also dangerous. Both scenarios entail complex philosophical questions and pose urgent challenges for supporters of democracy and human freedom, and the location of women and gender therein. The following section concludes this article with an overview of these questions, focusing in particular on the relationship between feminism and secularism within a framework of commitment to democracy and human rights in a globalized age. 


\section{conclusion: rethinking secularism as a feminist principle}

The need to re-examine established ways of thinking about secularism and its relationship to feminism has arisen in the context of the confluence of a number of developments in recent years including: the increasing dominance of the 'clash of civilizations' thesis; the expansion of progressive postmodern critiques of Enlightenment rationality to encompass questions of religion; and sustained critiques of the 'secularization thesis'. First, the egregious violence directed against 'the west' on September 1lth 2001 (and in subsequent bombings in London and Madrid) has been understood in ways that reinforce the cultural essentialist notion of a 'clash of civilizations' between a supposedly rational and free west and an irrational and oppressive Islam. In these debates, conservative positions centre on protecting western values and ensuring security against acts of terror, while progressive positions focus on challenging the abuses produced by this discursive logic, especially against Muslims living in or seeking entry to countries in the west.

In some European contexts this imagined clash of civilizations has played out particularly intensely around whether or not the state should ban different modes of Muslim women's dress in public settings (Skjeie, 2007). This is a reminder of the absolute centrality of women and gender power relations in the interrelation of religion, culture and the state. Moreover, because 'feminism', and the principle of women's equality with men, has been frequently instrumentalized in justifying punitive actions against Muslims and minority ethno-religious communities in the west, it is vital to contest such oppressive uses of feminism. This entails positing non-oppressive forms of feminism, which include rethinking the principle and practice of secularism. At the same time, however, much of the progressive side of these debates has paid insufficient attention to critical feminist analyses of the inimical impacts of some forms of multicultural politics and of trends (especially since 1980) towards the fusion of authoritarian religious forces and state power in global South contexts. New thinking on the interrelation of feminism and secularism, therefore, must be grounded in critiques of these developments as much as in critiques of Islamophobia and racism in the west.

The second development that prompts re-examination of the interplay of feminism and secularism is the expansion of progressive postmodern critiques of Enlightenment rationality to encompass questions of religion. From this perspective, the moral panic around Islam in Europe and the concomitant introduction of legal bans prohibiting forms of Muslim women's dress, come into focus as forms of state violence, justified through a rigid reading of the secular-religious binary. But does this mean that progressive minded feminism must jettison the principle of secularism? The feminist scholarship explored in this article addresses the interplay of gender, religion and power from different philosophical and 
disciplinary traditions and points of view. However, among those explicitly concerned with questions of religion in the public sphere, whether through communitarian, postmodern or what I call critical Enlightenment perspectives, important common tenets of analysis are emerging. All emphasize 'democracy' and the values that underpin it as the larger discursive frame in which ideas of secularism and secularity can be redefined with emancipatory intent. This common ground in democracy is, I argue, at the heart of non-oppressive articulations of feminism that both retain a commitment to norms of gender equality and human rights and actively respect women's differences, including in relation to religious identity.

Third, as shown in the literature reviewed in the section 'Rethinking secularization', it is now generally accepted that the presumption of secularization as an inevitable and singular process of modernization is no longer tenable. Empirical evidence shows much variation in how religion manifests across and within societies, at micro, meso and macro levels, and how its influence changes with other social changes, waxing or waning in different times, under different conditions. Importantly, it is also clear that there is significant variation in the vitality and significance of religion (and declared spirituality) across supposedly 'secular' liberal democracies under different models of formal 'church-state' relations. Recognizing this variability presents new challenges for how secularism is defined and operationalized in non-oppressive ways. Without the prop of secularization as inevitable, and challenged by postmodern critiques of the oppressive discursive logic of the secular-religious binary, there is an onus on defenders of secularism to own its status as a purely normative political principle. This means clearly defining the purpose of secularism and justifying its operation in specified contexts. It also entails moving away from a defence of secularism as a foundational principle and refocusing attention instead on its place in an emancipatory, inclusive account of the democratic polity. From this perspective, the principle of secularism is invoked to underpin the conditions of human freedom, including, among other things, respect for religious pluralism. Borrowing from the sociological rubric of neo-secularization, such an approach must be attentive to the 'scope of religious authority' in ways that: first, safeguard against violations of human freedom through the abuse of religious authority in various contexts; and second, as called for by feminist scholars in religion, eschew constructions of religion as only a constraint and the antithesis of freedom.

Any vision of feminism that aligns automatically with anti-religious expressions of secularism, or blanket condemnations of Muslim women's dress as an offensive symbol of the oppression of women, is untenable as a basis for emancipatory feminist practice in a globalized and neo-secular age. Elsewhere I have developed an account of cosmopolitan feminism that outlines the tenets of a nonoppressive globally oriented feminism (Reilly, 2007). It proceeds from the 
premise that on balance 'women have been and continue to be oppressed in diverse ways and for diverse reasons' (Karam, 1998: 5). Most importantly, however, cosmopolitan feminism entails recognition of the complex and often contradictory intersectionality of women's identities and experiences cutting across gender, socio-economic privilege, ethnicity, religion, sexuality, geolocation, and so on (Crenshaw, 1991; Brah and Phoenix, 2004; Yuval-Davis, 2006). It also requires recognition that this complexity can only be understood through dialogic practice. Embracing such a feminist ontology of intersectionality, then, demands that the content of any practical emancipatory agenda, aimed at transforming gender oppression, can only be formulated in mutually respectful dialogue. It can not be imposed by one group of women or men on another group of women in the name of feminism. Moreover, this cosmopolitan feminist perspective embeds feminism in democratic practice oriented towards the substantive realization of human rights and freedoms.

The strategies of the Malaysian non-governmental organization Sisters in Islam, as articulated by Norani Othman (2006) and Zainah Anwar (2009), offer a similar account of feminism in which religion features centrally. Othman argues that feminism in Malaysia must be a two-tiered struggle against gender discrimination and oppression emanating firstly from 'secular patriarchy' and, secondly, from more recent manifestations of 'Muslim patriarchy'. She expressly calls on the women's movement in Malaysia to directly address the impact of authoritarian politcized religion on the integrity of constitutionalism, respect for human rights and democracy. When fundamentalist forces permeate state power, she warns, breaches of religious or moral ethics, as determined by local religious leaders, are treated as criminal behaviour. (This is precisely the scenario that Habermas seeks to prevent by limiting religious speech to the informal public sphere.) Othman, however, goes beyond Habermas' safeguards by insisting on the importance of making links between religious and democratic, constitutional and human rights values within religious communities. Building on the ideas of Abdullahi An-Na'im (1992), Othman urges other devout Muslim women to reflect critically on the role of 'Islamic knowledge' in 'reclaiming the space for substantive democracy and justice' and to find a 'language of protest and resistance to religious and state authoritarianism' (Othman, 2006: 347). Finally, she stresses that the extent to which 'internal debate among Muslims can help to ... re-constitute women's rights and gender equality in Islam depends on the democratic space ... that exists in Muslim societies' (Othman, 2006: 352).

This vision articulated by Othman in a scenario of the deepening fusion of authoritarian religion and state power expresses an instructive feminist reading of the principle of secularism in a neo-secular age. In this vision, secularism underpins a dialogic public civil space that is defined above all by tolerance. Such a secular public space is far from anti-religious; it is a site of tolerance for 
competing interpretations of religious ideas within religions and respect vis-à-vis different religious and non-religious worldviews. In this regard it rejects the $\varepsilon C R$ as the antithesis of rationality and freedom even as she defends the principle of secularism as one of state neutrality vis-à-vis different religious communities and subjectivities. Othman's public space includes religious argument and expressions of religious identity as aspects of human self understanding, communication and development, and she admits religion as a legitimate discursive horizon in shaping (if not codifying in law) the ethical, moral and spiritual life of communities. Significantly, this vision calls for the active participation of religious women in critically reinterpreting religious concepts in emancipatory ways. Moreover, Othman sees such critical public debate as a pivotal mechanism in the substantive realization of women's rights and gender equality both within Islam (including in the family) and vis-à-vis the state. This account of a public sphere, which rejects the antithesis of religion and secularism, resembles Scott's suggestion of religion and the state operating as 'parallel systems of interpretation'. Othman, however, is less equivocal about what is required to ensure that the scope of religious authority exercised in such public spheres does not translate into the legitimization of gendered and other forms of oppression: a secular democratic state, grounded in constitutionalism and human rights, critically (re)interpreted from emancipatory feminist perspectives.

\section{acknowledgements}

I am indebted to two anonymous reviewers for detailed and very helpful comments that have contributed greatly to the final version of this article. All shortcomings of the article, however, are my own.

\section{author biography}

Dr Niamh Reilly is Senior Lecturer in Women's Studies at the School of Political Science and Sociology, National University of Ireland, Galway, where she is co-director of Global Women's Studies. She is the author of Women's Human Rights: Seeking Gender Justice in a Globalising Age (Polity Press, 2009) and has authored, co-authored and edited a number of other books. She has over 20 years' experience of teaching and research in the field of women's human rights and has worked extensively at UN level with international and national NGOs.

\section{references}

Al-Ali, N. (2000) Secularism, Gender \& the State in the Middle East: The Egyptian Women's Movement, Cambridge: Cambridge University Press.

Amin, S. and Hossain, S. (1994) 'Women's reproductive rights and the politics of fundamentalism: a view from Bangladesh' American University Law Review, Vol. 44, No. 4: 1319-1343. 
Anderson, P.S. and Clack, B. (2003) editors, Feminist Philosophy of Religion: Critical Readings, London: Routledge.

An-Na'im, A.A. (1992) editor, 'Toward a cross-cultural approach to defining international standards of human rights: the meaning of cruel, inhuman, or degrading treatment or punishment' Human Rights in Cross-Cultural Perspectives: A Quest for Consensus, Philadelphia: University of Pennsylvania Press.

An-Na'im, A.A. (2007) 'Global citizenship and human rights: from Muslims in Europe to European Muslims' in Loenen, M.L.P. and Goldschmidt, J.E. (2007) editors, Religious Pluralism and Human Rights in Europe: Where to Draw the Line? Antwerpen: Intersentia.

Anwar, Z. (2009) editor, Wanted: Equality and Justice in the Muslim Family, Selangor, Malaysia: Musawah.

Badran, M. (2009) Feminism in Islam: Secular and Religious Convergences, Oxford: Oneworld Pub.

Bayes, J.H. and Tohidi, N. (2001) editors, Globalization, Gender, and Religion: The Politics of Women's Rights in Catholic and Muslim Contexts, New York and Basingstoke: Palgrave.

Beattie, T. (2004) 'Redeeming Mary: the potential of Marian symbolism for feminist philosophy of religion' in Anderson, P.S. and Clack, B. (2004) editors, Critical Readings: Feminist Philosophy of Religion, London: Routledge.

Beattie, T. (2005) 'Religious identity and the ethics of representation: the study of religion and gender in the secular academy' in King, U. and Beattie, T. (2005) editors, Gender, Religion, and Diversity: Cross-Cultural Perspectives, London: Continuum.

Berger, P. (1999) The Desecularization of the World: The Resurgence of Religion in World Politics, Grand Rapids, MI: William B. Eerdmans.

Brah, A. and Phoenix, A. (2004) 'Ain't I a woman? Revisiting intersectionality' Journal of International Women's Studies, Vol. 5, No. 3: 75-86.

Bronner, S. (2004) Reclaiming the Enlightenment: Toward a Politics of Radical Engagement, New York: Columbia University Press.

Bruce, S. (1996) Religion in the Modern World: From Cathedrals to Cults, Oxford: Oxford University Press.

Bryson, V. (2003) Feminist Political Theory: An Introduction, 2nd edition, New York: Palgrave Macmillan.

Butler, J. (2008) 'Sexual politics, torture, and secular time' British Journal of Sociology, Vol. 59, No. 1: 1-23.

Casanova, J. (1994) Public Religions in the Modern World, Chicago: University of Chicago Press.

Casanova, J. (2008) 'Public religions revisited' in de Vries, H. (2008) editor, Religion: Beyond a Concept, New York: Fordham University Press.

Castelli, ع.A. (2001) 'Women, gender, religion: troubling categories and transforming knowledge' in Castelli, E.A. (2001) editor, Women, Gender, Religion: A Reader, New York: Palgrave/St. Martin's Press, 3-25.

Chaves, M. (1994) 'Secularization as declining religious authority' Social Forces, Vol. 72, No. 3: 749-774.

Christ, C.P. and Plaskow, J. (1979) Womanspirit Rising: A Feminist Reader in Religion, San Francisco: Harper.

Christ, C.P. and Plaskow, J. (1992) 'Preface to the 1992 edition' in Christ, C.P. and Plaskow, J. (1992) editors, Womanspirit Rising: A Feminist Reader in Religion, San Francisco: Harper, vii-xix.

Collins, P.H. (1990) Black Feminist Thought: Knowledge, Consciousness, and the Politics of Empowerment, New York: Routledge.

Cooke, M. (2007) 'A secular state for a postsecular society? Postmetaphysical political theory and the place of religion' Constellations, Vol. 14, No. 2: 224-238.

Cornell, D. (1998) At the Heart of Freedom: Feminism, Sex, and Equality, Princeton, NJ: Princeton University Press. 
Crenshaw, K. (1991) 'Mapping the margins: intersectionality, identity politics, and violence against women of color' Stanford Law Review, Vol. 43: 1241-1299.

Daly, M. (1978) Gyn/Ecology: The Metaethics of Radical Feminism, Boston: Beacon Press.

Davie, G. (2002) Europe - The Exceptional Case: Parameters of Faith in the Modern World, Maryknoll, Ny: Orbis.

Elshtain, J.B. (2009) 'Religion and democracy' Journal of Democracy, Vol. 20, No. 2: 5-17.

Fekete, L. (2004) 'Anti-Muslim racism and the European security state' Race \& Class, Vol. 46, No. 1: 3-29.

Furseth, I. and Repstad, P. (2006) An Introduction to the Sociology of Religion: Classical and Contemporary Perspectives, Aldershot: Ashgate.

Grewal, I. (1999) '"Women's rights as human rights": feminist practices, global feminism and human rights regimes in transnationality' Citizenship Studies, Vol. 3, No. 3: 337-354.

Gross, R. (1992) Buddhism after Patriarchy: A Feminist History, Analysis and Reconstruction of Buddhism, New York: SUNY Press.

Gross, R.M. (1996) Feminism and Religion: An Introduction, Boston: Beacon Press.

Habermas, J. (2008) 'Religion in the Public Sphere: Cognitive Presuppositions for the 'Public Use of Reason' by Religious and Secular Citizens' in Between Naturalism and Religion: Philosophical Essays, Cambridge: Polity Press, 114-147.

Harding, S. (2004) editor, The Feminist Standpoint Theory Reader: Intellectual and Political Controversies, New York: Routledge.

Hartsock, N.C.M. (1998) The Feminist Standpoint Revisited and Other Essays, Boulder, CO: Westview Press.

Heelas, P., Woodhead, L., Seel, B., Szerszynski, B. and Tusting, K. (2005) The Spiritual Revolution: Why Religion Is Giving Way to Spirituality, Oxford: Blackwell.

Herbert, D. (2003) Religion and Civil Society: Rethinking Public Religion in the Contemporary World, Aldershot: Ashgate.

Horkheimer, M. and Adorno, T. (1972) Dialectic of Enlightenment, translated by John Cumming. New York: Herder and Herder.

Imam, A. and Yuval-Davis, N. (2004) 'Introduction' in Imam, A., Morgan, J. and Yuval-Davis, N. (2004) editors, Warning Signs of Fundamentalisms, London: Women Living under Muslim Laws.

Jeffery, P. and Basu, A. (1998) Appropriating Gender: Women's Activism and Politicized Religion in South Asia, London: Routledge.

Karam, A.M. (1998) Women, Islamisms and the State: Contemporary Feminisms in Egypt, London: Macmillan.

Kiliç, S., Saharso, S. and Sauer, B. (2008) 'Introduction: the veil: debating citizenship, gender and religious diversity' Social Politics: International Studies in Gender, State \& Society, Vol. 15, No. 4: 397-410.

King, U. (1995) editor, Gender \& Religion, Oxford: Basil Blackwell.

King, U. and Beattie, T. (2005) editors, Gender, Religion, and Diversity: Cross-Cultural Perspectives, London: Continuum.

Levey, G.B. and Modood, T. (2009) editors, Secularism, Religion and Multicultural Citizenship, Cambridge: Cambridge University Press.

Lorde, A. (1984) 'An Open Letter to Mary Daly', Sister Outsider: Essays and Speeches, Berkeley, CA: The Crossing Press.

Malesevic, V. (2010) 'Ireland and neo-secularisation theory' Irish Journal of Sociology, Vol. 18, No. 1.

McCann, C.R. and Kim, S. (2010) editors, Feminist Theory Reader: Local and Global Perspectives, 2nd edition, New York: Routledge.

McLaughlin, J. (2003) Feminist Social and Political Theory: Contemporary Debates and Dialogues, New York: Palgrave Macmillan. 
Modood, T., Triandafyllidou, A. and Zapata-Barrero, R. (2006) editors, Multiculturalism, Muslims and Citizenship, London: Routledge.

Mohanty, C.T. (1988) 'Under western eyes: feminist scholarship and colonial discourses' Feminist Review, Vol. 30: 65-88.

Mohanty, C.T. (2003) 'Under western eyes revisited: feminist solidarity in anti-capitalist struggles' in Mohanty, C.T. (2003) editor, Feminism Without Borders: Decolonizing Theory, Practicing Solidarity, Durham, NC: Duke University Press.

Mukhtar, A.A. (2003) 'Working within Sharia takes you only so far' Human Rights Dialogue, Vol. 2, No. 10: 26.

Narayan, U. (2000) 'Essence of culture and a sense of history: a feminist critique of cultural essentialism' in Narayan, U. and Harding, S. (2000) editors, Decentering the Center: Philosophy for a Multicultural, Postcolonial and Feminist World, Bloomington: Indiana University Press.

Norris, P. and Inglehart, R. (2004) Sacred and Secular: Religion and Politics Worldwide, Cambridge: Cambridge University Press.

Nussbaum, M.C. (2000) Sex \& Social Justice, New York: Oxford University Press.

Okin, S.M. (1992) Women in Western Political Thought, Princeton, NJ: Princeton University Press.

Okin, S.M. (1999) 'Is multiculturalism bad for women?' in Okin, S.M., Cohen, J., Howard, M. and Nussbaum, M.C. (1999) editors, Is Multiculturalism Bad for Women? Princeton, NJ: Princeton University Press.

Othman, N. (2006) 'Muslim women and the challenge of Islamic fundamentalism/extremism: an overview of Southeast Asian Muslim women's struggle for human rights and gender equality' Women's Studies International Forum, Vol. 29, No. 4: 339-353.

Pathak, Z. and Sunder Rajan, R. (1992) 'Shahbano' in Butler, J. and Scott, J.W. (1992) editors, Feminists Theorize the Political, New York: Routledge.

Plaskow, J. (2001) 'The academy as real life: new participants and paradigms in the study of religion' in Castelli, E.A. (2001) editor, Women, Gender, Religion: A Reader, New York: Palgrave/ St. Martin's Press.

Plaskow, J. and Christ, C.P. (1989) Weaving the Visions: New Patterns in Feminist Spirituality, San Francisco: HarperCollins.

Razak, S.H. (2008) Casting Out: The Eviction of Muslims from Western Law and Politics, Toronto: University of Toronto Press.

Reilly, N. (2007) 'Cosmopolitan feminism and human rights' Hypatia: A Journal of Feminist Philosophy, Vol. 22, No. 4: 180-198.

Reilly, N. (2009) Women's Human Rights: Seeking Gender Justice in a Globalizing Age, London: Polity Press.

Saghal, G. (2004) 'Two cheers for multiculturalism' in Imam, A., Morgan, J. and Yuval-Davis, N. (2004) editors, Warning Signs of Fundamentalisms, London: Women Living under Muslim Laws.

Sandel, M.J. (2006) Public Philosophy: Essays on Morality in Politics, Cambridge, MA: Harvard University Press.

Schüssler Fiorenza, $\varepsilon$. (1984/1994) In Memory of Her: A Feminist Theological Reconstruction of Christian Origins, 10th ann. edition, New York: Crossroad.

Scott, J.W. (2007) The Politics of the Veil, Princeton, NJ: Princeton University Press.

Shaheed, F. (1989) 'Women, religion and social change in Pakistan: A proposed framework for research - draft. An international centre for ethnic studies project (1988-1989)' Dossier 5-6, December 1988-May 1989, London: Women Living under Muslim Laws, http://www.wluml.org/ node/261, accessed 17 July 2010.

Shaheed, F. (2004) Dossier 26: constructing identities - culture, women's agency and the Muslim world, http://www.wluml.org/node/478, accessed 11 November 2010. 
Shaheed, F. (2009) 'Gender, religion and the quest for justice in Pakistan' Final Research Report prepared for the project Religion, Politics and Gender Equality of the United Nations Research Institute for Social Development (UNRISD), September, http://www.wemc.com.hk/web/e-bulletin/ 01-2010/files/df.pdf, accessed 17 July 2010.

Sharma, A. (1987) editor, Women in World Religions, Albany: State University of New York Press.

Silvestri, S. (2010) 'Europe's Muslims: Burqa laws, women's lives' Open Democracy, 15 July, http:// www.opendemocracy.net/sara-silvestri/french-burqa-and-\%ع2\%80\%9Cmuslim-integration \% ₹2\% 80\%9D-in-europe, accessed 17 July 2010.

Skjeie, H. (2007) 'Headscarves in schools: European comparisons' in Loenen, M.L.P. and Goldschmidt, J.E. (2007) editors, Religious Pluralism and Human Rights in Europe: Where to Draw the Line? Antwerpen: Intersentia.

Starhawk (1979) The Spiral Dance: A Rebirth of the Ancient Religions of the Great Goddess, San Francisco: Harper.

Stepan, A.C. (2000) 'Religion, democracy, and the "twin tolerations"' Journal of Democracy, Vol. 11, No. 4: 37-57.

Taylor, C. (2009) 'Foreword' in Levey, G.B. and Modood, T. (2009) editors, Secularism, Religion and Multicultural Citizenship, Cambridge: Cambridge University Press.

Tripp, A.M., Kwesiga, J., Casimiro, I. and Mungwa, A. (2009) African Women's Movements: Transforming Political Landscapes, Cambridge: Cambridge University Press.

Vincett, G., Sharma, S. and Aune, K. (2008) editors, 'Introduction: women, religion and secularization: one size does not fit all' in Women and Religion in the West: Challenging Secularization, Aldershot: Ashgate.

Woodhead, L. (2008) 'Gendering secularisation theory' Social Compass, Vol. 55, No. 2: 189-195.

Young, I.M. (2002) Inclusion and Democracy, Oxford: Oxford University Press.

Yuval-Davis, N. (2006) 'Intersectionality and feminist politics' European Journal of Women's Studies, Vol. 13, No. 3: 193-209.

doi: $10.1057 /$ fr. 2010.35 